\title{
Sub-zero temperature enables storage of seeds of Caesalpinia echinata Lam. ${ }^{1}$
}

\author{
Juliana Iura de Oliveira $\mathrm{Mello}^{2}$, Rita de Cássia Leone Figueiredo-Ribeiro², \\ Claudio José Barbedo ${ }^{3 *}$
}

\begin{abstract}
Seeds of brazilwood usually have their germinability quickly reduced if stored under natural conditions. Low temperatures, mainly sub-zero, can extend this viability for at least two years. However, there is no information about the germination behavior of these seeds for longer periods, aiming at the germoplasm bank formation. The objective of this work was to evaluate the viability of brazilwood seeds during five-year storage period at 2,8 and $-18{ }^{\circ} \mathrm{C}$. Before storage, seeds were subjected to artificial drying $\left(50^{\circ} \mathrm{C}\right)$ until the moisture content reached $10 \%$. The germination and the normal seedling development of seeds maintained at low temperatures did not differ from other treatment during the first year of storage. However, after two years only seeds stored at $-18{ }^{\circ} \mathrm{C}$ kept high germination percentage. Seeds stored for five years at $-18{ }^{\circ} \mathrm{C}$ showed high values of germination and normal seedling development; however, after this period it was possible to identify some symptoms of seed deterioration. Storage at sub-zero temperatures is considered as an important initiative to maintain Caesalpinia echinata seed banks, contributing to the conservation of plant biodiversity.
\end{abstract}

Index terms: brazilwood, conservation, freezing, Leguminosae.

\section{Temperatura sub-zero possibilita o armazenamento de sementes de Caesalpinia echinata Lam.}

\begin{abstract}
RESUMO - Sementes de pau-brasil geralmente têm sua germinação rapidamente reduzida quando armazenadas em condições naturais. As temperaturas baixas, principalmente inferiores a $0{ }^{\circ} \mathrm{C}$, podem estender essa viabilidade por até dois anos. No entanto, não há informações sobre a germinação de sementes dessa espécie, quando submetidas a períodos mais longos de armazenamento, visando à formação de banco de germoplasma. O objetivo deste trabalho foi avaliar a viabilidade de sementes de pau-brasil durante o armazenamento por cinco anos em câmaras com temperaturas de 2,8 ou $-18^{\circ} \mathrm{C}$. Antes do armazenamento, as sementes foram submetidas a secagem artificial $\left(50^{\circ} \mathrm{C}\right)$ até atingirem $10 \%$ de água. A germinação e o desenvolvimento de plântulas a partir de sementes mantidas em ambiente com temperaturas inferiores a $0{ }^{\circ} \mathrm{C}$ não foram diferentes dos demais tratamentos, durante $\mathrm{o}$ primeiro ano de armazenagem. No entanto, após dois anos, as armazenadas a $-18{ }^{\circ} \mathrm{C}$ mantiveram porcentagem de germinação superior às conservadas nas demais temperaturas. Sementes armazenadas por cinco anos a $-18{ }^{\circ} \mathrm{C}$ apresentaram valores elevados de germinação, com elevada porcentagem de desenvolvimento das plântulas, porém com indícios de início de deterioração. $\mathrm{O}$ armazenamento em temperaturas inferiores a $0{ }^{\circ} \mathrm{C}$ pode ser uma ferramenta importante para manutenção de bancos de sementes de Caesalpinia echinata, contribuindo para a conservação da biodiversidade vegetal.
\end{abstract}

Termos para indexação: congelamento, conservação, Leguminosae, pau-brasil.

\section{Introduction}

Caesapinia echinata Lam., brazilwood, was included in 1992 in the list of the Instituto Brasileiro do Meio Ambiente e dos Recursos Naturais Renováveis (IBAMA) as a species at risk of extinction and remained in that list until recent days (Pilatti et al., 2011). Its wood, before exploited to obtain reddish

${ }^{1}$ Submitted on 06/11/2013. Accepted for publication on 09/23/2013.

${ }^{2}$ Instituto de Botânica, Núcleo de Pesquisa em Fisiologia e Bioquímica de Plantas, Caixa Postal 8041, 04045-972 - São Paulo, SP, Brasil. dye, is nowadays used to manufacture musical arcs, since it has exceptional qualities, and the high demand includes the illegal international trade (Franco and Yojo, 2008). This was one of the reasons for inclusion, by IBAMA, of $C$. echinata among woody plant species economically important to the risk of extinction (Pilatti et al., 2011). Due to its historical and ecological importance, several actions were taken in an attempt

${ }^{3}$ Instituto de Botânica, Núcleo de Pesquisa em Sementes, Caixa Postal 68041 , 04045-972 - São Paulo, SP, Brasil.

*Corresponding author <claudio.barbedo@pesquisador.cnpq.br> 
to conserve this species, such as the formation of forests and arboretums of the species in various regions of the country (Rocha, 2010) and the creation of laws on the worldwide marketing of the species (Lamarca and Barbedo, 2012).

The natural range of the brazilwood stretches from the Rio de Janeiro to Rio Grande do Norte (Rocha, 2010); however, it is limited to a small number of individuals, which reinforces the fact that the ex situ preservation is extremely important. For this species, the ex situ conservation through germplasm banks is still unfeasible.

The formation of seed banks could be an important genetic reservoir for long periods (Santos, 2000). However, for seeds of some species, the conventional storage techniques, which include drying and storage at low temperatures in order to reduce the metabolism, is not enough to prevent the deterioration (Parisi et al., 2013). This was demonstrated, for example, in seeds of brazilwood in which oxidative processes, including respiration and the action of free radicals, are probably related to the rapid deterioration (Lamarca and Barbedo, 2012). The higher the temperature, the more rapid was the deterioration of these seeds, that was similar to seeds of Jatropha curcas L., as observed by Pinto Junior et al. (2012) and Pereira et al. (2013), and to seeds of Tabebuia caraiba (Mart.) Bureau, as observed by Guedes et al. (2012).

Brazilwood seeds, when stored at room temperature, usually lose their viability within a month (Barbedo et al., 2002), but it is possible to extend their viability when dried and stored at low temperatures $\left(7^{\circ} \mathrm{C}\right)$. In freezing conditions $\left(-18^{\circ} \mathrm{C}\right)$, Hellmann et al. (2006) were able to keep them viable for two years, with a high percentage of normal seedlings. This was the same period described by Zanotti et al. (2012) for storage in liquid nitrogen conditions $\left(-196^{\circ} \mathrm{C}\right)$. However, this period is still not enough for the effective success of its conservation in germplasm banks. Thus, the present study aimed to verify the maintenance of seed viability of brazilwood after long-term storage (up to five years) under freezing conditions.

\section{Material and Methods}

Caesalpinia echinata Lam. seeds were harvested at maturity directly from trees just before shedding (Borges et al., 2005) in a homogeneous crop (ca. 250) located in the Biological Reserve and Experimental Station at Moji-Guaçu (22 $\left.{ }^{\circ} 15-16^{\prime} \mathrm{S}, 4^{\circ} 8-12^{\prime} \mathrm{W}\right)$, State of São Paulo, Brazil.

Seed water content ( $\%$, on a fresh mass basis) and the seed

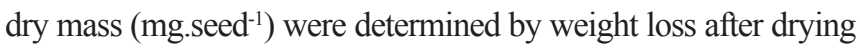
during $17 \mathrm{~h}$ at $103 \pm 3{ }^{\circ} \mathrm{C}$ (Brasil, 2009) using four replicates of three seeds each. Germination (protrusion of the primary root) was carried out in germination chambers (Marconi MA400, Piracicaba,
Brazil) at $25^{\circ} \mathrm{C}$, in plastic box $(11 \times 11 \times 3 \mathrm{~cm})$ with vermiculite moistened previously with tap water, with four replications of 12 seeds each (Mello and Barbedo, 2007) and the germination test was evaluated every three days.

After the initial characterization, the seeds were submitted to artificial drying in an oven $\left(50^{\circ} \mathrm{C}\right)$ until reach $10 \%$ of water, according to previously studies (Barbedo et al., 2002). Following, seeds were stored in paper bags in three different temperatures: $7 \pm 3{ }^{\circ} \mathrm{C}$ (RH: $45 \pm 7 \%$ ), $2 \pm 2{ }^{\circ} \mathrm{C}(\mathrm{RH}: 29 \pm 2 \%$ ), and $-18 \pm$ $5{ }^{\circ} \mathrm{C}$ (RH: $84 \pm 10 \%$ ). A control sample was kept in laboratory ambient temperatures and relative humidity $\left(22 \pm 7^{\circ} \mathrm{C}, \mathrm{RH}: 80 \pm\right.$ $15 \%$ ). Seed viability during storage at different temperatures was evaluated after six months, one, two, three, four and five years through germination tests. The moisture content of the seeds was also evaluated in each treatment.

Data were statistically analyzed by the $F$ test at the $5 \%$ level of probability and were compared by Tukey test $(\mathrm{p}<0.05)$. It was used a completely randomized design in a factorial scheme $3 \times 7$ (storage temperatures $\mathrm{x}$ storage periods) (Pimentel Gomes, 1982).

\section{Results and Discussion}

Seeds stored at $22^{\circ} \mathrm{C}$, which initially possessed about $80 \%$ germination, were already dead in the first evaluation performed after six months of storage, thus confirming previous information about the low storability of $C$. echinata seeds under environments without temperature control (Barbedo et al., 2002; Lamarca and Barbedo, 2012).

Seed water content did not change significantly within each temperature after the first three years. The positive temperatures $\left(8\right.$ and $2{ }^{\circ} \mathrm{C}$ ) favored large reduction of the water content within the first six months of seed storage (Table 1). However, seeds remained almost with the same water content after this period. Nonetheless the storage under freezing temperatures kept the seeds with higher water content, but it also remained almost constant after the first six months of storage by the end of the experimental period.

Although the seeds kept at $+8{ }^{\circ} \mathrm{C}$ and $+2{ }^{\circ} \mathrm{C}$ have shown great reduction in water content, these seeds remained viable during the first year and, until the first six months, showed no significant difference in the percentage of germination compared to seeds kept frozen and do not loose water during storage (Figure 1). Significant differences between the values of germination of seeds stored under positive temperatures were observed only after one year and remained until the last period, after five years of storage. Seeds stored at $-18^{\circ} \mathrm{C}$ apparently began to lose viability only after five years. 
Table 1. Variations in the water content (\%) of Caesalpinia echinata stored at different temperatures. Small letters compare storage temperature and capital letters compare storage time. (Tukey's test, $P<0.05, \mathrm{n}=4$ ).

\begin{tabular}{ccccr}
\hline $\begin{array}{c}\text { Storage } \\
\text { temperature }\end{array}$ & \multicolumn{5}{c}{$\begin{array}{c}\text { Storage time } \\
\text { (months) }\end{array}$} \\
\hline$\left({ }^{\circ} \mathrm{C}\right)$ & 6 & 12 & 24 & 36 \\
\hline$+2^{\circ} \mathrm{C}$ & $6.2 \mathrm{bB}$ & $6.0 \mathrm{bB}$ & $7.0 \mathrm{bA}$ & $5.1 \mathrm{bC}$ \\
$+8^{\circ} \mathrm{C}$ & $6.5 \mathrm{bA}$ & $6.2 \mathrm{bA}$ & $5.5 \mathrm{cB}$ & $5.1 \mathrm{bB}$ \\
$-18^{\circ} \mathrm{C}$ & $10.9 \mathrm{aAB}$ & $11.2 \mathrm{aA}$ & $9.5 \mathrm{aC}$ & $10.6 \mathrm{aB}$ \\
\hline C.V. $(\%)$ & 2.7 & & & \\
\hline
\end{tabular}

The results of germination until the second year of storage were similar to those reported by Barbedo et al. (2002), Hellmann et al. (2006) and Zanotti et al. (2012). However, these authors did not evaluate longer periods of storage as in the present study, in which it was demonstrated that positive temperature storage promoted complete loss of $C$. echinata seed viability within three years; these findings invalidate any possible idea of preserving germplasm of this species at temperatures that are not negative. It reinforces, therefore, that negative temperatures are needed to reduce oxidative reactions that lead to rapid deterioration of $C$. echinata seeds (Lamarca and Barbedo, 2012).

Results of germination and normal seedling development are indicative of maintenance of seed vigor when stored at temperatures lower than $0{ }^{\circ} \mathrm{C}$ (Figures 1 and 2). Despite the germination of seeds stored at $-18{ }^{\circ} \mathrm{C}$ was reduced only after five years, the values of normal seedlings development showed that deterioration started after two years of storage. Although the percentage of seeds that produced normal seedlings has been elevated during the five years at $-18^{\circ} \mathrm{C}$ storage, the decreases observed from one to two years suggest a some degree of seed deterioration. Therefore, even substantially increasing the storage capacity of $C$. echinata seeds at sub-zero temperature, it was an evidence that the process of rapid deterioration already reported in previous researches (Barbedo et al., 2002; Hellmann et al., 2006) has not yet been satisfactorily controlled.

Taking into consideration only the number of germinated seeds, the average time of germination is also an interesting test for seed vigor evaluation. Results of this test were capable to identify the level of seed deterioration when stored at different temperatures, which corroborated the information provided by the results of normal seedlings, indicating that seed vigor was effectively lowered at all temperatures, particularly in the positive ones (Figure 3). There was an initial decrease in average time of germination from six to 12 month, for all storage temperatures. This fact did not mean, however, that there was an increase in seed vigor, but that non-stored seeds could show some degree of dormancy or that needed a period of post-harvest to attain full maturity.

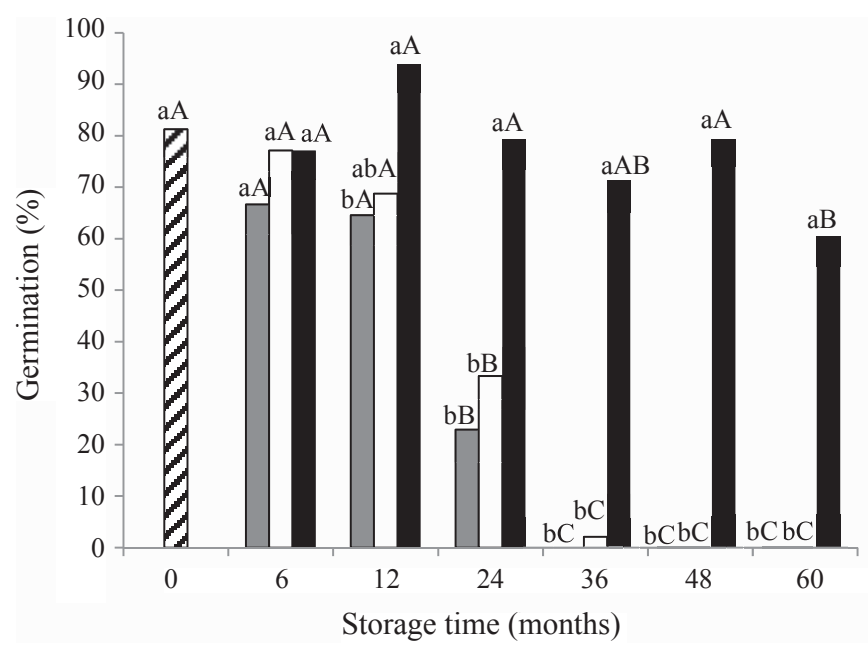

Figure 1. Germination (\%) of Caesalpinia echinata at time zero (striped bar) and after different periods of storage at $+8{ }^{\circ} \mathrm{C}$ (gray bar), $+2{ }^{\circ} \mathrm{C}$ (white bar) and $-18{ }^{\circ} \mathrm{C}$ (black bar). Small letters compare storage temperatures and capital letters compare storage time (Tukey's test, $P<0.05, \mathrm{n}=4$ ).

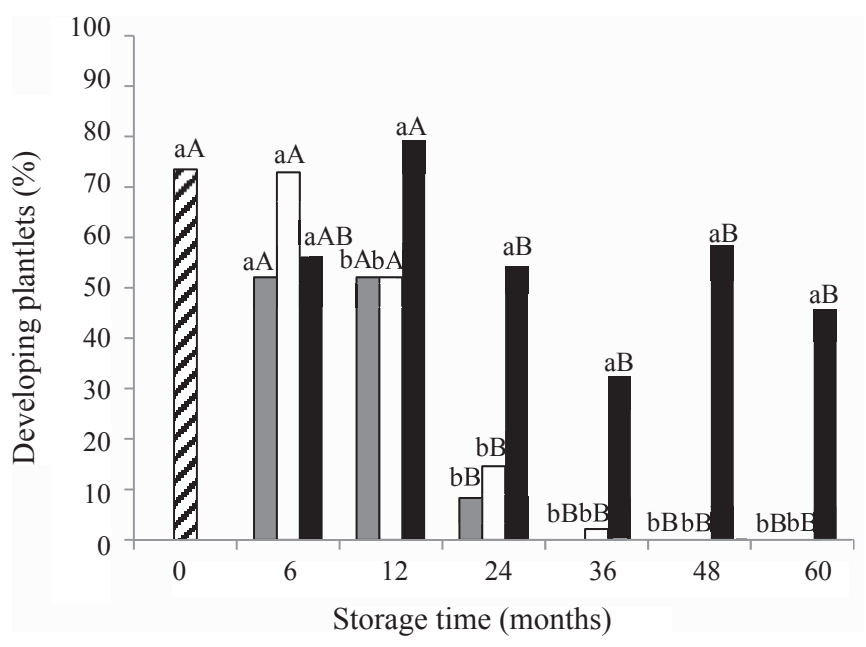

Figure 2. Development of normal seedlings (\%) from the seeds of Caesalpinia echinata at time zero (striped bar) and after different periods of storage at $+8{ }^{\circ} \mathrm{C}$ (gray bar), $+2{ }^{\circ} \mathrm{C}$ (white bar) and $-18^{\circ} \mathrm{C}$ (black bar). Small letters compare storage temperatures and capital letters compare storage time (Tukey's test, $P<0.05, \mathrm{n}=4$ ).

The mean time to germination of seeds stored under positive temperatures increased from 12 months to two years, thus indicating the beginning of deterioration. At third year, the average time of germination of these seeds was zero (or 
very close to zero) and this was not caused by an increase in vigor, but by the low germination percentage (Figure 1). Moreover, seeds stored at $-18{ }^{\circ} \mathrm{C}$ maintained the average germination time from 12 months to five years, showing that this test is not sensitive enough to diagnose decreases in seed vigor, as pointed out by the values of normal seedlings.

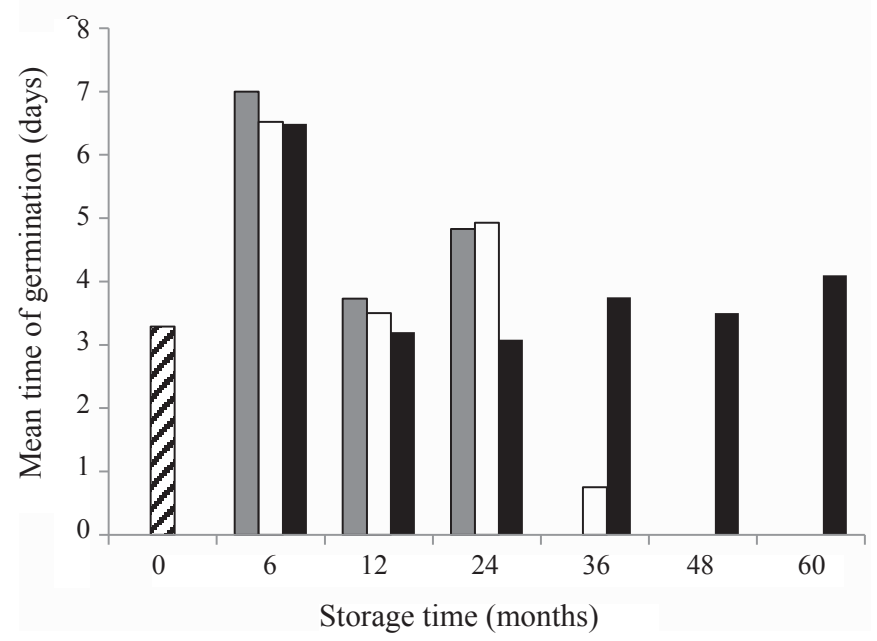

Figure 3. Mean germination time (days) of Caesalpinia echinata at time zero (striped bar) and after different periods of storage at $8{ }^{\circ} \mathrm{C}$ (gray bar), $+2{ }^{\circ} \mathrm{C}$ (white bar) and $-18^{\circ} \mathrm{C}$ (bar black).

Results of this study showed that brazilwood seeds should be stored at sub-zero temperatures. However, it should be worth to control the values of water content, which decreased significantly during storage at positive temperatures (Table 1). These results suggested that the deterioration of such seeds would not have occurred depending on the temperature, but on the decrease in seed moisture content. In this case, however, it would be expected a reduction in seed germination as in the first six months of storage, since at this time the seeds had reached the water content maintained up to the end of the storage. Another important factor to consider is that the seeds of $C$. echinata are tolerant to desiccation, supporting reductions up to $4 \%$ (N. Martini Neto, 2012, personal communication). Since the water content of the seeds stored was never lower than 5\%, it is assumed that deterioration does not occur due to the water content. This idea is reinforced by the results obtained by Lamarca and Barbedo (2012) which set the water content of seeds and submitted them to different temperatures. These authors found that the oxidative processes occur so progressively more intense with any increase in environmental temperature.

Another important aspect concerning seed water content, as already reported by Hellmann et al. (2006), is that brazil wood seeds of high water content does not survive at subzero temperatures, possibly by mechanical damage in cell membranes caused by the expansion of freeze water. It is also important to evaluate changes in the composition of the seeds once Garcia et al. (2006) found changes in carbohydrates during storage of seeds of C. echinata and Mello et al. (2011) showed that the lipids of these seeds could also be involved with the changes in germination after storage.

The orthodox seed storage at $-18^{\circ} \mathrm{C}$ is adopted by most seed banks, allowing prolonged seed longevity for many decades (Santos, 2000). Considering that seeds of C. echinata tolerate exposure to liquid nitrogen (Zanotti et al., 2012), at very low temperatures, it is possible to speculate that they retain their ability to germinate for periods longer than those obtained in the present work. Once the seed production of Brazil wood is annual, the possibility to store their seeds for at least five years can serve as an important tool for conservation of the species symbol of the country, still regarded as endangered.

\section{Conclusions}

The storage of seeds of Caesalpinia echinata at $-18{ }^{\circ} \mathrm{C}$ maintain their germinability for, at least, five years.

\section{Acknowledgments}

This work is part of J.I.O.M. doctoral thesis at the Plant Biodiversity and Environment Program/Instituto de Botânica, and was supported by Fundação de Amparo à Pesquisa do Estado de São Paulo (FAPESP, Grant 05/04139-7). J.I.O.M. thanks Conselho Nacional de Desenvolvimento Científico e Tecnológico (CNPq) for the DR fellowship C.J. Barbedo and R.C.L. FigueiredoRibeiro are researchers associated with Conselho Nacional de Desenvolvimento Científico and Tecnológico (CNPq).

\section{References}

BARBEDO, C.J.; BILIA, D.A.C.; FIGUEIREDO-RIBEIRO, R.C. L. Tolerância à dessecação e armazenamento de sementes de Caesalpinia echinata Lam. (pau-brasil). Revista Brasileira de Botânica, v.25, p.431-439, 2002. http://www.scielo.br/pdf/rbb/v25n4/a07v25n4.pdf

BORGES, I.F.; GIUDICE NETO, J.D.; BILIA, D.A.C.; FIGUEIREDORIBEIRO, R.C.L.; BARBEDO, C.J. Maturation of seeds of Caesalpinia echinata Lam. (Brazilwood), an endangered leguminous tree from the Brazilian Atlantic Forest. Brazilian Archives of Biology and Technology, v. 48, p. 851-861, 2005.

BRASIL. Ministério da Agricultura, Pecuária e Abastecimento. Regras para análise de sementes. Ministério da Agricultura, Pecuária e Abastecimento. Secretaria de Defesa Agropecuária. Brasília: MAPA/ACS, 2009. 395p. http:// www.agricultura.gov.br/arq_editor/file/2946_regras_analise_sementes_pdf 
FRANCO, N.; YOJO T. Propriedades físicas, mecânicas e acústicas da madeira de pau-brasil. In: FIGUEIREDO-RIBEIRO, R.C.L.; BARBEDO, C.J.; ALVES, E.S.; DOMINGOS, M.; BRAGA, M.R. (Orgs.). Pau-brasil: da semente à madeira: conhecer para preservar. São Paulo: Instituto de Botânica, 2008. p.154-158.

GARCIA, I.S.; SOUZA, A.; BARBEDO, C.J.; DIETRICH, S. M.C.; FIGUEIREDO-RIBEIRO, R.C.L. Changes in soluble carbohydrates during storage of Caesalpinia echinata LAM. (brazilwood) seeds, an endangered leguminous tree from the brazilian atlantic forest. Brazilian Journal of Biology, v.66, p.739-745, 2006. http://www.scielo.br/pdf/bjb/v66n2b/30162.pdf

GUEDES, R.S.; ALVES, E.U.; MELO, P.A.R.F.; MOURA, S.S.S.; SILVA, R.S. Storage of Tabebuia caraiba (Mart.) Bureau seeds in different packaging and temperatures. Revista Brasileira de Sementes, v.34, p.433-440, 2012. http://www.scielo.br/pdf/rbs/v34n3/10.pdf

HELLMANN, M.E.; MELLO, J.I.O.; FIGUEIREDO-RIBEIRO, R.C.L.; BARBEDO, C.J. Tolerância ao congelamento de sementes de pau-brasil (Caesalpinia echinata Lam.) influenciada pelo teor de água. Revista Brasileira de Botânica, v.29, p.93-101, 2006. http://www.scielo.br/pdf/\%0D/ $\mathrm{rbb} / \mathrm{v} 29 \mathrm{n} 1 / \mathrm{a} 09 \mathrm{v} 29 \mathrm{n} 1 . \mathrm{pdf}$

LAMARCA, E.V.; BARBEDO, C.J. Short storability of Caesalpinia echinata Lam. seeds as a consequence of oxidative processes. Hoehnea, v.39, p.577586, 2012. http://www.scielo.br/pdf/hoehnea/v39n4/06.pdf

MELLO, J.I.O.; BARBEDO, C.J. Temperatura, luz e substrato para germinação de sementes de pau-brasil (Caesalpinia echinata Lam., Leguminosae - Caesalpinioideae). Revista Árvore, v.31, p.645-655, 2007. http://www.scielo.br/pdf/rarv/v31n4/09.pdf

MELLO, J.I.O.; CENTENO, D.C.; BARBEDO, C.J.; FIGUEIREDORIBEIRO, R.C.L. Changes in carbohydrate composition in seeds of three tropical tree species submitted to drying and storage at freezing temperature. Seed Science and Technology, v.39, p.465-480, 2011. http://www. ingentaconnect.com/content/ista/sst/2011/00000039/00000002/art00018

PARISI, J.J.D.; BIAGI, J.D.; BARBEDO, C.J.; MEDINA, P.F. Viability of Inga vera Willd. subsp. affinis (DC.) T. D. Penn. embryos according to the maturation stage, fungal incidence, chemical treatment and storage. Journal of Seed Science, v.35, p.70-76, 2013. http://www.scielo.br/pdf/jss/v35n1/10.pdf
PEREIRA, M.D.; DIAS, D.C.F.S.; BORGES, E.E.L.; MARTINS FILHO, S.; DIAS, L.A.S.; SORIANO, P.E. Physiological quality of physic nut (Jatropha curcas L.) seeds during storage. Journal of Seed Science, v.35, p.21-27, 2013. http://www.scielo.br/pdf/jss/v35n1/03.pdf

PILATTI, F.K.; AGUIAR, T.; SIMÕES, T.; BENSON, E.E; VIANA, A.M. In vitro and cryogenic preservation of plant biodiversity in Brazil. In Vitro Cell. Dev. Biol. Plant, v.47, p.82-98, 2011. http://link.springer.com/article/10.1007/ s11627-010-9302-y

PIMENTEL GOMES, F. Curso de estatística experimental. 10. ed. Piracicaba: Nobel, 1982.468p.

PINTO JUNIOR, A.S.; GUIMARÃES, V.F.; DRANSKI, J.A.L.; STEINER, F.; MALAVASI, M.M; MALAVASI, U.C. Armazenamento de sementes de pinhão manso em diferentes embalagens e ambientes. Revista Brasileira de Sementes, v.34, p.636-643, 2012. http://www.scielo.br/pdf/rbs/v34n4/15.pdf

ROCHA, Y.T. Distribuição geográfica e época de florescimento do pau-brasil (Caesalpinia echinata Lam. - Leguminosae). Revista do Departamento de Geografia, v.20, p.23-36, 2010. http://citrus.uspnet.usp.br/rdg/ojs/index.php/ rdg/article/view/4/2

SANTOS, I.R.I. Criopreservação: potencial e perspectivas para a conservação de germoplasma vegetal. Revista Brasileira de Fisiologia Vegetal, v.12, p.7084, 2000. http://www.cnpdia.embrapa.br/rbfv/pdfs/v12Especialp70.pdf

ZANOTTI, R.F.; MOTTA, L.B.; BRAGATTO, J.; LABATE, C.A.; SALOMÃO, A.N.; VENDRAME, W.A.; CUZZUOL, G.R.F. Germination, carbohydrate composition and vigor of cryopreserved Caesalpinia echinata seeds. Brazilian Archives of Biology and Technology, v.55, p. 661-669, 2012. http://www.scielo.br/pdf/babt/v55n5/04.pdf 